Chiefs 


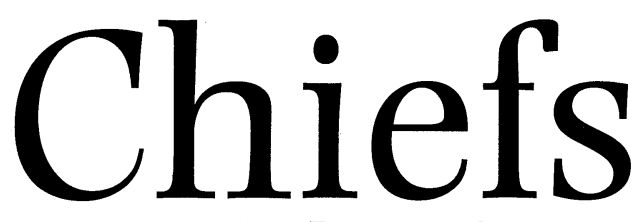

in South Africa

Law, Power \& Culture

in the Post-Apartheid Era

\section{BARBARA OOMEN}

Assistant Professor of Law \& Development

University of Amsterdam

James Currey

OXFORD

University of KwaZulu-Natal Press

PIETERMARITZBURG 
James Currey Ltd

73 Botley Road

Oxford OX2 OBS

www.jamescurrey.co.uk

University of KwaZulu-Natal Press

Private Bag X01

Scottsville, 3209

South Africa

www.ukznpress.co.za

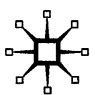

First published in the United States by

PALGRAVE, 175 Fifth Avenue, New York, NY 10010

Companies and representatives throughout the world, PALGRAVE is the new global imprint of St. Martin's Press, LLC Scholarly and Reference Division and Palgrave Publishers Ltd (formerly Macmillan Press Ltd)

All rights reserved. No part of this book may be reproduced in any form, or by electronic, or mechanical means, including information storage and retrieval systems, without permission in writing from the publishers, except by a reviewer who may quote brief passages in a review.

(C) Barbara Oomen 2005

First published 2005 Softcover reprint of the hardcover 1st edition 2005 978-1-4039-7085-5

123450908070605

ISBN 978-1-349-73576-1

ISBN 978-1-137-06460-8 (eBook)

DOI 10.1007/ 978-1-137-06460-8

British Library Cataloguing in Publication Data Oomen, Barbara

Chiefs in South Africa

1. Tribal government - South Africa 2. South Africa Politics and government - 1994

I. Title

$321.1^{\prime} 0968$

Library of Congress Cataloging-in-Publication Data available on request

Typeset in 10/11 pt Photina by Long House, Cumbria

Transferred to Digital Printing 2012 


\section{CONTENTS}

List of Acronyms

Acknowledgements

viii

Photographs

\section{Introduction}

\section{Reawakenings}

1. The dawning of the dawn 1

2. A new world

The nation-state - New politics - Renegotiating the culture card -

The rise of 'rights to roots' - The resurgence of the traditional leaders

3. Past nightmares

Culture and colonialism - The creation of customary law -

The character of bureaucratic chieftaincy

4. Theoretical challenges

Law, power, culture - The constitutive effects of cultural rights

legislation - The resurgence of traditional leadership

5. An approach to the study

'The locality' - Traditional leaders, living law - A place - Methods

6. Outline of the study

\section{The Patchwork Democracy}

Boundary Politics after 1994

1. Introduction

2. The legacy

3. Imagining the future: constitutional negotiations

1991-1992: Talks about talks - 1993: Formulating the interim

Constitution - 1994-1996: Drafting the final Constitution

4. Towards a Traditional Authorities Act

5. 'Two bulls in a kraal?': the local government discussion The Local Government Transition Act - The White Paper and new municipal legislation - The 2000 implementation crisis

6. Keeping control over land

Hanekom: the socialist years - Didiza: back to traditional communities

7. The customary law debates

Relations: customary law and the Bill of Rights - Rules:

the Law Commission's harmonisation project - Guarding the customary courts

8. Conclusion 


\section{The Power of Definition}

Struggling for the Soul of Custom $\quad 87$

1. Introduction $\quad 87$

2. Who did the defining? The actors 90

The African National Congress - The IFP and some unlikely allies -

Contralesa: chiefs in politics - The civics: a wilting counterweight -

The Traditional Affairs officials

3. Why could they? Signs of the times

Party-political power - Path dependency - The quest for an

African identity - Transformations of the state - The rise of group rights

4. The assumptions

Rural-urban difference - Community-think - Coherent systems of customary law - Chiefly legitimacy

5. Conclusion

\section{Sekhukhune}

\section{The Institutional Landscape}

1. Introduction

2. From Bopedi to Lebowa

3. Traditional leadership and its spheres

Palace politics - Bureaucracy - Party politics

4. The institutional landscape

Elected local government - Government departments - The civics - Mapogo a

Mathamaga - The churches - Organisations of business and migrants

5. Asserting control

Control over resources - Control over boundaries -

Control over people - Control over meaning

6. Conclusion

\section{5. 'Walking in the middle of the road'}

People's Perspectives on the Legitimacy of Traditional Leadership 164

1. Chieftaincy and legitimacy

2. How do people support chiefs?

Within limits - Issue-related - Not exclusive - Dynamic

3. Support at community level

Hoepakranz: out on the mountains - Ga-Masha: one step away from riches -

Mamone: retraditionalisation in a fast-changing world

4. Support dependent on chiefly characteristics

Supporting chiefs, supporting chieftaincy - Virtues and vices of traditional leaders

5. Support at the individual level

'This is a thing of our parents': the youth and the elders -

The paradox of the women - Moving up, moving out: education and income

6. Why do people support traditional leaders?

'These are our roots': traditional legitimacy - 'They do good things for us':

performance as a source of legitimation - 'They guard us for the government' 'What else is there?': default legitimation

7. Conclusion 


\section{Negotiated Laws, Relational Rights}

Power, Authority $\&$ the Creation of Local Law

1. Introduction

2. Living law and legal culture in Sekhukhune

Plurality of forums - Negotiated law - State law as a resource -

Relational rights - A processual legal culture

3. Stories of succession

Succession: the official version - Living law - Interactions - Illustrations

4. The Commission on the Tribal Constitution

5. Conclusion

\section{Conclusion}

\section{Categories have Consequences}

The Constitutive Effects of Cultural Rights Legislation

1. Introduction

2. Definitions and struggles

3. The constitutive effects of cultural rights legislation

4. Law, power and culture

5. Alternatives 


\section{List of Acronyms}

$\begin{array}{ll}\text { ANC } & \text { African National Congress } \\ \text { CODESA } & \text { Convention for a Democratic South Africa } \\ \text { Contralesa } & \text { Congress of Traditional Leaders of South Africa } \\ \text { CP } & \text { Constitutional Principle (as in Act 200/1993) } \\ \text { CP } & \text { Conservative Party } \\ \text { CPA } & \text { Communal Property Association } \\ \text { DC } & \text { District Council } \\ \text { DFA } & \text { Development Facilitation Act (67/1995) } \\ \text { DLA } & \text { Department of Land Affairs } \\ \text { DNA } & \text { Department of Native Affairs } \\ \text { ECOWAS } & \text { Economic Community of West African States } \\ \text { EU } & \text { European Union } \\ \text { GNMT } & \text { Greater Ngwaritsi Makhudu/Thamaga } \\ \text { IDP } & \text { Integrated Development Plan } \\ \text { IFP } & \text { Inkatha Freedom Party } \\ \text { ILO } & \text { International Labour Organisation } \\ \text { IMF } & \text { International Monetary Fund } \\ \text { IPACC } & \text { Indigenous Peoples of South Africa Co-ordinating Committee } \\ \text { LGTA } & \text { Local Government Transition Act (209/1993) } \\ \text { MEC } & \text { Member of the Executive Committee } \\ \text { MINMEC } & \text { Minister and Members of the Executive Committee } \\ \text { MP } & \text { Member of Parliament } \\ \text { MPNP } & \text { Multi-Party Negotiation Process } \\ \text { NG } & \text { Nederlands Gereformeerd (church) } \\ \text { NGO } & \text { Non-governmental organisation } \\ \text { NLC } & \text { National Land Committee } \\ \text { NP } & \text { National Party } \\ \text { PAC } & \text { Pan Africanist Congress } \\ \text { RDP } & \text { Reconstruction and Development Programme } \\ \text { SACP } & \text { South African Communist Party } \\ \text { SADEC } & \text { Southern African Development Community } \\ \text { SADF } & \text { South African Defence Force } \\ \text { SALGA } & \text { South African Local Government Association } \\ \text { SANCO } & \text { South African National Civics Organisation } \\ \text { TLC } & \text { Transitional Local Council } \\ \text { TUSAA } & \text { Trade Union of South African Authorities } \\ \text { TMC } & \text { Transitional Metropolitan Council } \\ \text { TRC } & \text { Transitional Representative Council } \\ \text { UDF } & \text { United Democratic Front } \\ \text { UDM } & \text { United Democratic Movement } \\ \text { UN } & \text { United Nations } \\ \text { WGIA } & \text { Working Group of Indigenous Minorities in Southern Africa } \\ & \end{array}$




\section{Acknowledgements}

'A chief is like the moon; if it shines it is because of the sun and stars that surround it,' a Sotho saying goes. If there is any merit in this work, which deals with the reappraisal of chiefs and custom in contemporary South Africa, it is because of all the people who have enlightened me on the subject over the past years. Without the wonderful literature already published, the protracted e-mail conversations with colleagues, the brief chats and the long interviews in South African offices and homesteads, in conference hallways or in the Van Vollenhoven Institute over coffee, this book would simply not exist. And even if there is no way of illuminating the whole constellation that facilitated the research, I would like to start by expressing my deepest gratitude to at least part of it - without, of course, placing responsibility on anyone but myself for possible errors in this final product.

Firstly, there are all those people in Sekhukhune who so generously opened their courts, palaces and houses to a - at times overtly - curious stranger. That they were prepared to do so was mostly thanks to my cheerful research companion Patson Phala, who spoke the language of kings and commoners, men and women, pensioners and youngsters alike, and was always prepared to throw in a joke or a good story if our interviews threatened to become too tedious. The fact that the farewell party we threw after the field research was attended by so many people was not only because of the two giant cooking pots full of nama and bogobe, but also because there were simply so many people to thank. Within this group, Tsepo Pasha, Welsh Ratau, the royal families of Kgoloko, Masha, Nkosi, Sekhukhune and Sekwati, the Nkosi family, the brothers Kgalema, Dankie Lesaba, Elias Sepodumo, Teshell Shikwambane, Toko Suteka, Philip Vilakazi and Jacob Zulu exemplify the hospitality and friendship I encountered in Bopedi. It is my sincere hope that this study and its recommendations will somehow, in the long run, not only benefit the academic community but also all those Bapedi whose resourcefulness and patience I have come to admire so much.

Part of my field research was conducted high up in the Leolo mountains, while a cottage kindly loaned to me by the Sekhukhune Educare Project in the bustling township of Jane Furse formed another base. Here, in the evenings, my laptop linked me to a wide community of ever-supportive colleagues - some of whom I have never met personally, but who commented on wild thoughts and early drafts, and generally gave me the impression that I was on to something worthwhile. There is no way of expressing, for instance, my gratitude to John Comaroff for taking an interest in the research, reading research memos and finally - meticulously and perspicaciously commenting on the draft manuscript. Similarly, I have learnt a great deal from and appreciated the interest shown by Pat McAllister, Tom Bennett, Erhard Blankenburg, Martin Chanock, Peter Delius, Marnix de Bruyne, Martin Doornbos, Willemien du Plessis, Axel Harnett-Sievers, Manfred Hinz, André Hoekema, Deborah James, Freddy Khunu, Ian Liebenberg, Mahmood Mamdani, Patrick Mtshaulane, Kennedy Mojela, Annika Mökvist, 
Christina Murray, Thandabantu Nhlapo, Carl Niehaus, Seth Nthai, Lungisile Ntsebeza, Nic Olivier, Roel Pieterman, Steven Robins, Albie Sachs, Theo Scheepers, Eltjo Schrage, Peter Skalnik, Robert Thornton, Kees Van der Waal, Franz and Keebet Von Benda-Beckmann, Olufemi Vaughan, Louis Vorster and Mike Williams.

Back at Leiden University, I once again felt that a student of African law could not wish for a better academic home. The vibrant African Studies Centre, under the direction of (lawyer) Gerti Hesseling, not only has a great library collection and staff, but also provided me with a platform where I could share and discuss ideas. I am particularly obliged to Ineke van Kessel, Robert Ross and Emile van Rouveroy van Nieuwaal for their genuine and continuous interest in my work. In addition, the anthropologists in Peter Geschiere's Africanist $\mathrm{PhD}$ seminar welcomed me to their ranks, never making me - as a lawyer and a political scientist - feel like the odd one out. Other research networks proved to be equally stimulating: the 'South Africa PhDs' with Erik Bähre, Julia Hornberger and Wiebe Nauta; the 'Law and Culture' group with Kristin Henrard and Saskia Tempelman as close comrades; the Centre for Non-Western Studies with its colleagues like Laila Al-Zwaini and Ellen-Rose Kambel, and the research networks of the Meijers Institute on both social cohesion and global governance. Outside Leiden, I highly appreciated the continuous flow of information provided by Kairos staff members Hans Hartman and Erik van den Bergh, as well as the intellectual support and friendship of colleagues like Gerhard Anders, Arne Musch and Joris van der Sandt.

Also, I could not have wished for a warmer and more friendly base than the Van Vollenhoven Institute for Law, Governance and Development. If the VVI emulated McDonalds in choosing an 'employee of the month', Adriaan Bedner would be a long-time title-holder, both for his interest in the work of others as well as for the astuteness of his comments on it. Maaike de Langen, on the other hand, would be a close runner-up, not least because of her good-natured acceptance of my neglect of other obligations while I was wrapping up this thesis. Julia Arnscheidt, Albert Dekker, Nel de Jong, Sylvia Holverda, Carola Klamer, John McCarthy, Harold Munneke, David Nickolson, Nicole Niessen, Sebastiaan Pompe, Benjamin van Rooij and Janine Ubink all read drafts, gave literature tips and generally made it a great pleasure to work at the Institute. Marianne Moria and Kari van Weeren worked very hard to provide practical support, while Amin Kassam is to be complimented on his speedy and thorough editing.

Of all the strange customs I encountered in Sekhukhune, few could beat the tradition at Leiden University of not thanking one's supervisors at the end of a $\mathrm{PhD}$ trajectory. This preface to the book that came out of that $\mathrm{PhD}$ would not be complete without an expression of sincere gratitude to Jan-Michiel Otto for the wisdom and understanding with which he guided me through the various phases of the research. Co-supervisor Stephen Ellis brought great insight into both African affairs and human relations, and the discussions the three of us had on the manuscript played no small role in ensuring that I enjoyed the research until the very end.

Now that this work has been completed (even if my interest in the subject has only increased) I would have loved to have showed it to Drü Sutton, who played such an important role in my life and with whom I hitchhiked around South Africa in the year after Mandela walked free. Sadly, he did not live to see the 
result of my first infatuation with his country, and the book is dedicated to him. There are many others close to me to thank, for a variety of reasons, but I would like to single out my parents Janus and Tonny Oomen, and my friends Margreet Korsten and Roeland Ris for their interest, not only in the author of this research, but also in the work itself. Finally, for all the small and large stars that guided me in conducting this research, there can only be one sun: Herman Lelieveldt's support went far beyond what is usual for even the best of partners. After having played an important role in the research design, he specialised in (and published on) 'how to write your PhD'. And when it was time to wrap the whole thing up, he helped by creating the best of natural deadlines and remedies against postdissertation depression: our radiant son Tom. For all this, I am immensely grateful. 


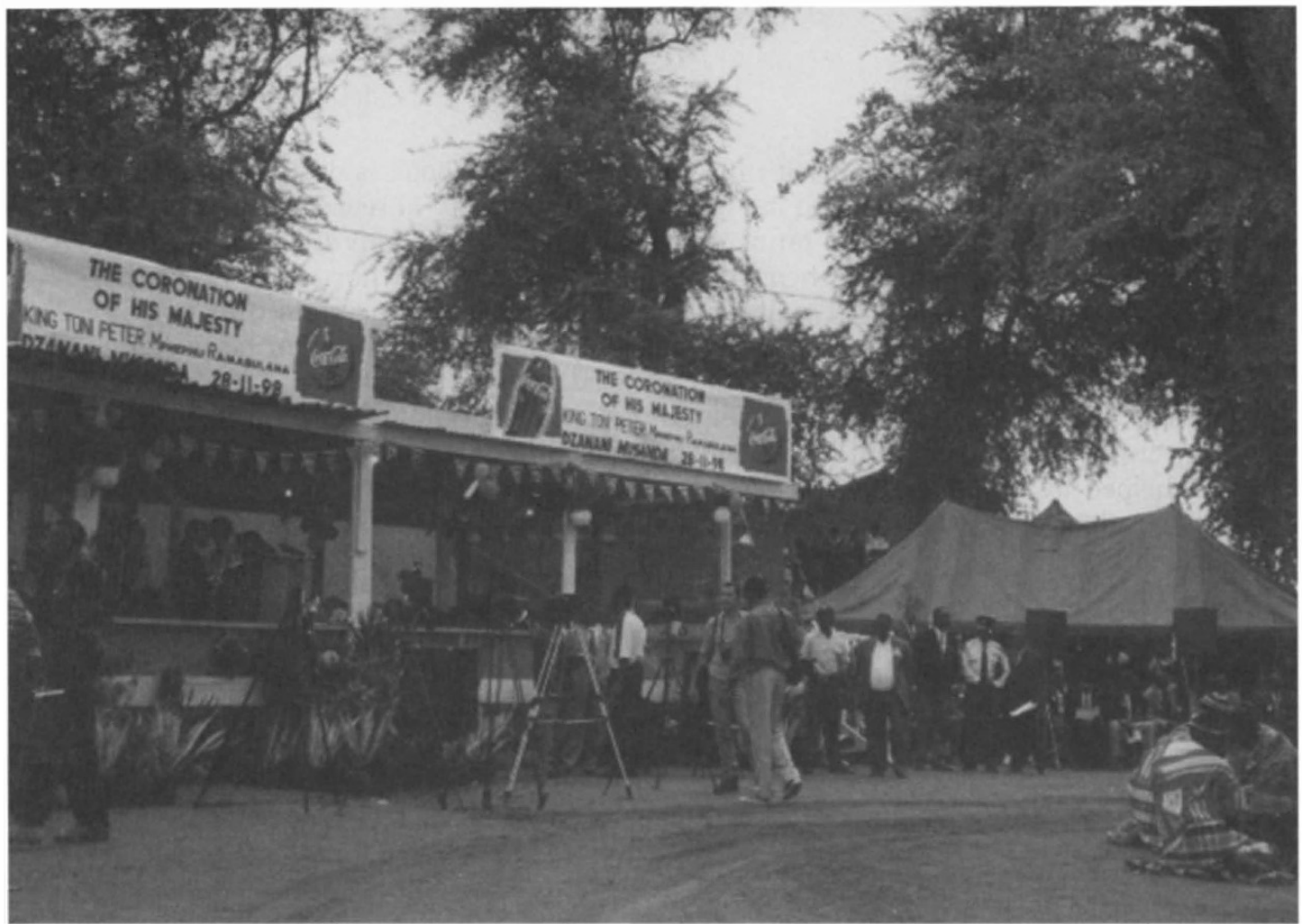

1. The coronation of Chief Ramabulana in Venda, at which President Nelson Mandela was also present (all photographs (C) Barbara Oomen)

2. The Kgôrô; the re-instated customary court in Mamone (see p.141)

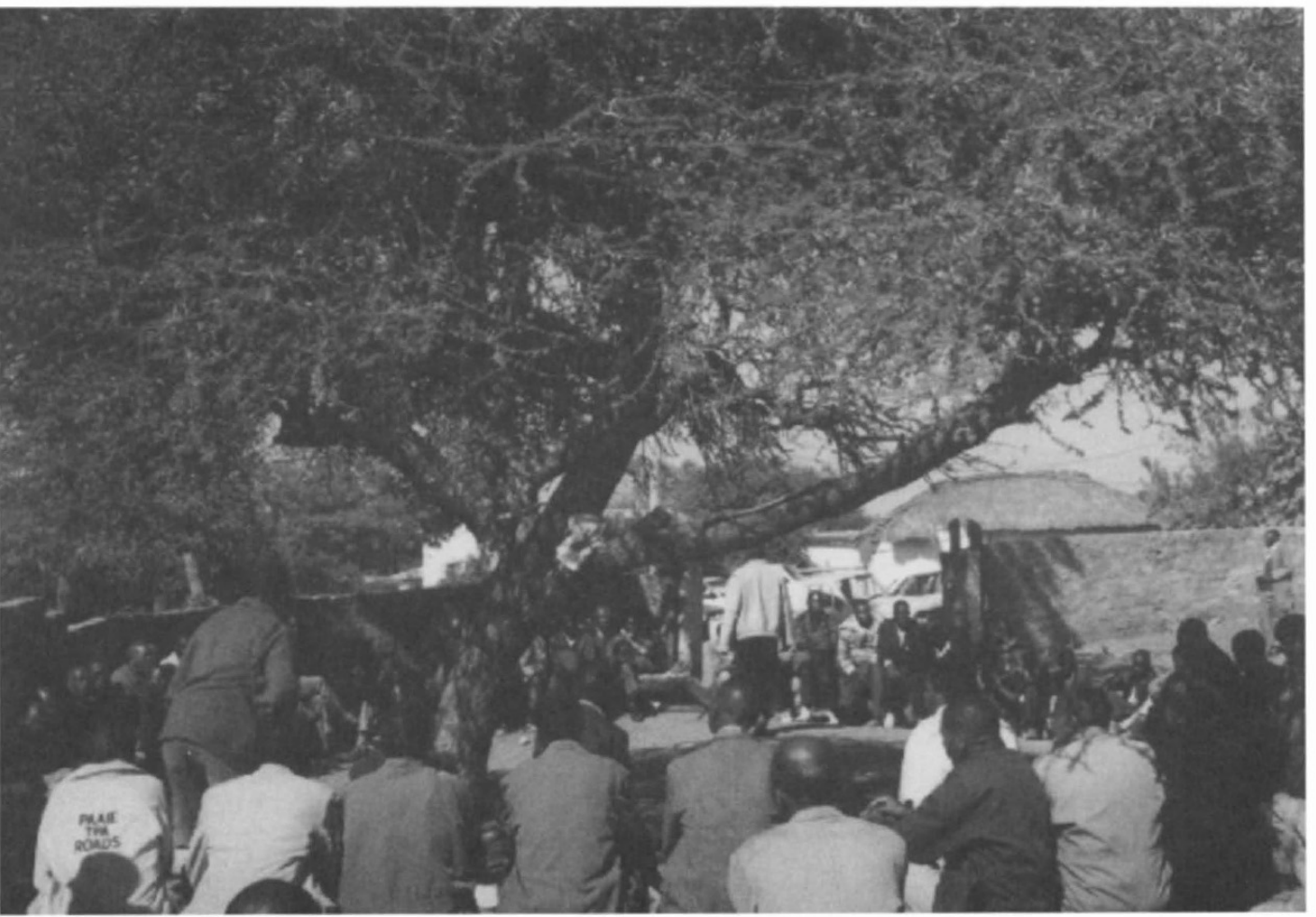


3. Kgosi Billy Sekwati Mampuru in leopard skin purchased by migrants upon his coronation, during a 'heritage day' for schoolchildren

4. Retraditionalisation in Mamone: Kgosi Billy Sekwati Mampuru III and his wife during his coronation (see p.123)
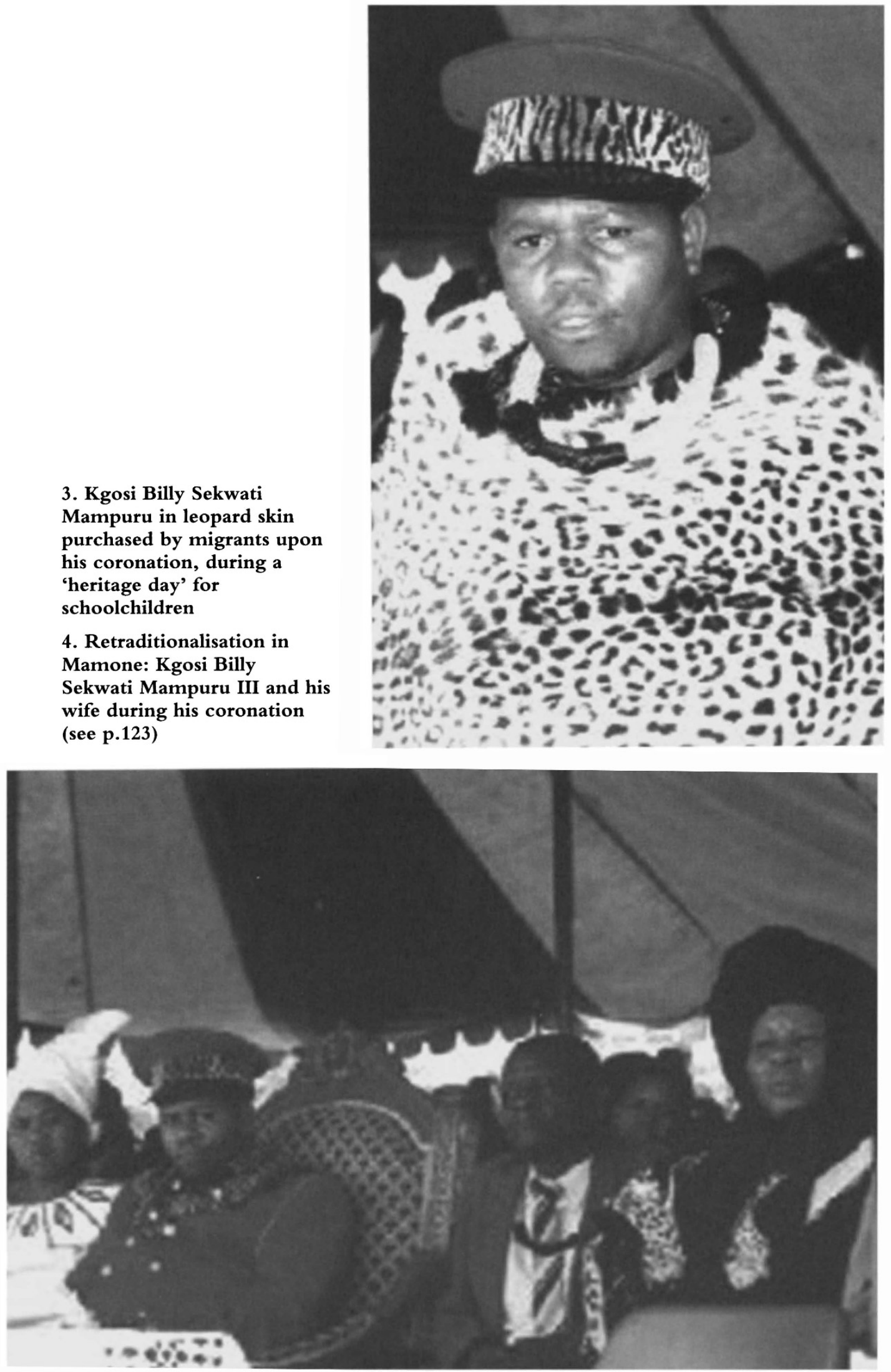
7. One of the many people present during president Mandela's visit to

Sekhukhuneland (see p.142)

8. Member of the vigilante organisation Mapogo a Mathamaga ('If you are a leopard, I'll be a tiger', see p.149)
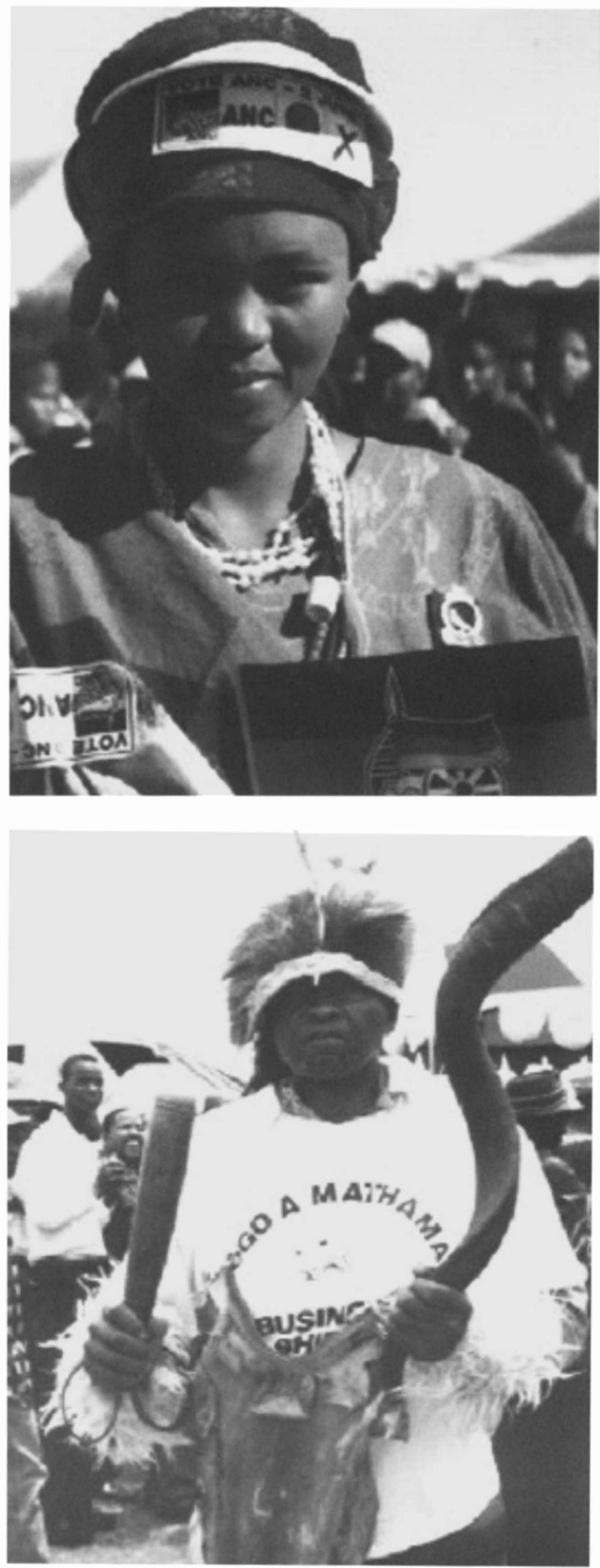